\title{
Author/Subject Indexes Vol. 16, No. 1, 1996
}

Author Index Vol. 16, No. 1,1996

Agodoa, L.Y. 7 Becker, B.N. 60 Bullard,A. 79 Butterly, D.W. 45 Calemard, E. 35 Charra,B. 35 Chertow, G.M. 79 Delmez,J.A. 29 Depner, T.A. 17 Hakim, R.M. 60 Held,P.J. 7

Ismail, N. 60 Jones, C.A. 7 Laurent, G. 35 Lazarus, J.M. 79 Maidment, HJ. 52 Petersen, J. 52

Schulman, G. 5 Schwab, SJ. 45 Stivelman, J.C. 73 Windus,D.W. 29

Subject Index Vol. 16, No. 1,1996

Adequacy 29, 35

Blood pressure 35

Calcitriol 73

Compartment analysis 17

Delivery 29

Dextran 73

Dialysis 45

- dose 7

Dialyzer 29

Endotoxin 60

End-stage renal disease 79

Erythropoietin 73

ESRD 7

Formaldehyde 52

Glutaraldehyde advantages, disadvantages

52 Hemodialysis 17,29,35,73,79 Incidence 7 Iron 73 Kt/V 7, 17

Limulus amoebocyte lysate assay 60

Malnutrition 79

Medications 73

Modeling 17

Mortality 7

Nutritional assessment 79

Peracetic acid 52

Peritoneal dialysis 79

Pyrogenic reactions 60

Quantification 17

Recirculation 29

Reuse 52

Reverse osmosis 60

Survival 35

Treatment time 35

Urea kinetic modeling 45

- kinetics 17 
USRDS 7

Vancomycin 73

Vascular access 29, 45

90 